\title{
Environmental Surveillance of Polioviruses in Rio de Janeiro, Brazil, in Support to the Activities of Global Polio Eradication Initiative
}

\author{
Joseane Simone de Oliveira Pereira ${ }^{1} \cdot$ Lidiane Rodrigues da Silva $^{1}$.

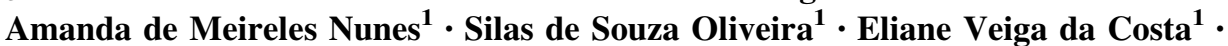 \\ Edson Elias da Silva ${ }^{1}$
}

Received: 8 June 2015/Accepted: 26 October 2015/Published online: 4 November 2015

(c) The Author(s) 2015. This article is published with open access at Springerlink.com

\begin{abstract}
Wild polioviruses still remain endemic in three countries (Afghanistan, Pakistan, and Nigeria) and reemergency of wild polio has been reported in previously polio-free countries. Environmental surveillance has been used as a supplementary tool in monitoring the circulation of wild poliovirus (PVs) and/or vaccine-derived PVs even in the absence of acute flaccid paralysis cases. This study aimed to monitor the presence of polioviruses in wastewater samples collected at one wastewater treatment plant located in the municipality of Rio de Janeiro, Brazil. From December 2011 to June 2012 and from September to December 2012, 31 samples were collected and processed. $\mathrm{RD}$ and L20B cell cultures were able to isolate PVs and non-polio enteroviruses in $27 / 31$ samples. Polioviruses were isolated in eight samples (type 1 Sabin $=1$, type 2 Sabin $=5$, and type 3 Sabin $=2$ ). Vaccine-derived polioviruses were not detected nor evidence of recombination with other PVs or non-polio enterovirus serotypes were observed among the isolates. The Sabin-related serotypes 2 and 3 presented nucleotide substitutions in positions associated with the neurovirulent phenotype at the $5^{\prime}$ UTR. Changes in important Amino acid residues at VP1 were also observed in the serotypes 2 and 3. Environmental surveillance has been used successfully in monitoring the circulation of PVs and non-polio enteroviruses and it is of crucial importance in the final stages of the WHO global polio eradication initiative. Our results show the
\end{abstract}

Edson Elias da Silva

edson@ioc.fiocruz.br

1 Enterovirus Laboratory, Oswaldo Cruz Institute, Avenida Brasil 4365, Manguinhos, Rio de Janeiro, RJ CEP 21040-360, Brazil continuous circulation of Sabin-like PVs and non-polio enteroviruses in the analyzed area during the study period.

Keywords Poliovirus - Poliomyelitis · Environmental surveillance $\cdot$ Polio eradication

\section{Introduction}

Poliomyelitis (acute anterior poliomyelitis and infantile paralysis) is characterized by a clinical feature of flaccid paralysis of sudden onset (http://www.who.int/media centre/factsheets/fs114/en/). The disease mainly affects children under five years of age and is caused by one of the three poliovirus (PVs) serotypes (PV1, PV2, and PV3) (Pallansch and Roos 2001), which belong to the Enterovirus genus of the family Picornaviridae (Racaniello 2001; Wimmer et al. 1993).

The global polio eradication initiative was launched in 1988 (CDC 1993; Dowdle et al. 2003; Kew et al. 2005). Since then the incidence of wild PVs transmission has dramatically declined (>99\%) (GPEI 2015). However, by March of 2015, wild polioviruses still remain endemic in three countries (Afghanistan, Pakistan, and Nigeria). Until $\mathrm{PVs}$ transmission is interrupted in these countries, all countries remain at risk of importation of polio. In fact, cases of re-emergency have been reported in previously polio-free countries (GPEI 2015).

In the process of eradication, the oral polio vaccine (OPV) has played a crucial role, both by its ease in administration, favoring high vaccine coverage rates, as well as by greater spread of the vaccine virus via the fecaloral (Carvalho and Weckx 2006). However, as genetically unstable genomes, the attenuated PVs phenotypes present in the OPV may suffer mutations giving rise to rare cases 
of vaccine-associated poliomyelitis as well as vaccinederived polioviruses (VDPV) (Kew et al. 2005).

Non-synonymous mutations that may occur at the VP1 gene may change amino acid residues at codons recognized to be associated with the attenuated phenotype of prototype strains. The amino acid residues known to be responsible for OPV attenuation markers are $\mathrm{A}^{88}$ residues $\mathrm{T}^{106}$ and $\mathrm{F}^{134}$ in Sabin serotype 1 (Rouchaud et al. 1995); the residue $\mathrm{I}^{143}$ Sabin serotype 2 (Macadam et al. 1993) and the residue $T^{6}$ in Sabin serotype 3 (Weeks-Levy et al. 1991; Tatem et al. 1992). Several mutations lead to the replacement of amino acid $\mathrm{I} \rightarrow \mathrm{T}$ in serotype 2 ; however, other changes in the same amino acid has been observed in smaller proportions $(\mathrm{I} \rightarrow \mathrm{V}, \mathrm{I}$ and $\mathrm{S} \rightarrow \mathrm{I} \rightarrow \mathrm{N}$ ) (Mueller et al. 2009).

Another well-characterized attenuating mutations in the Sabin strains are mutations located in the $5^{\prime}$-untranslated region (5'-UTR) (Minor 1992). These mutations have been identified in PVs of Sabin type $3(472 \mathrm{U} \rightarrow \mathrm{C})$ (Cann et al. 1984), type $2(481 \mathrm{~A} \rightarrow \mathrm{G})$ (Macadam et al. 1993), and type $1(480 \mathrm{G} \rightarrow \mathrm{A}$ and $525 \mathrm{U} \rightarrow \mathrm{C}$ ) (Otelea et al. 1993) and are believed to selectively affect initiation of translation of viral polyprotein in neuronal cells (Svitkin et al. 1990; Guest et al. 2004).

Environmental surveillance of polioviruses has been used as a supplementary tool in monitoring the circulation of wild PVs and/or VDPV in environmental samples supposedly contaminated by human feces, even in the absence of reported AFP cases (Hovi 2006; Hovi et al. 2012; WHO 2003).

The last paralytic case caused by wild indigenous PVs occurred in Brazil in 1989. Although Brazil has maintained high rates of OPV coverage ( $>95 \%$ ) (MS 2013), the nonoccurrence of poliomyelitis caused by wild polioviruses is not sufficient to reject the risk of reintroduction of wild polioviruses from endemic regions. Therefore, environmental surveillance of PVs is essential in order to detect and monitor the circulation of wild PVs and/or VDPVs even in the absence of reported AFP cases (WHO 2003).

The present study aimed to establish the environmental surveillance of PVs in the Enterovirus Laboratory, FIOCRUZ, Brazil (WHO Regional Reference Laboratory) in support to the WHO polio global eradication initiative, in the city of Rio de Janeiro, Brazil.

\section{Materials and Methods}

\section{Sample Collection}

Rio de Janeiro city is one of the 92 municipalities of the Rio de Janeiro State, located in the Southeastern Brazil. This municipality has an area of $1200 \mathrm{~km}^{2}$ with approximately 6453,682 inhabitants (IBGE 2014) and is served by wastewater treatment plants (WWTPs). Among the WWTPs, the Alegria/Cedae was chosen because it attends a population of about 1,500,000 inhabitants.

From December 2011 to June 2012 and from September to December 2012, a total of 31 composite samples were collected from the WWTP Alegria/CEDAE once a week. Several aliquots were collected by the grab method during a $12 \mathrm{~h}$ period in a total volume of $1.0 \mathrm{~L}$ of sewage sample. Samples were transported at 4 to $8{ }^{\circ} \mathrm{C}$ to the Laboratory.

\section{Sample Preparation}

Sewage samples were divided into two aliquots of $500 \mathrm{ml}$ each. An aliquot of $500 \mathrm{ml}$ was stored at $-20{ }^{\circ} \mathrm{C}$ as a backup while the other one was concentrated (100-fold) to $5 \mathrm{ml}$ using the silica-adsorption method (Boom et al. 1990; Leisinger and Metzler 1997; Baggi et al. 2001; van Heerden et al. 2005) essentially as detailed by Zurbriggen et al. (2008). The concentrate was treated with antibiotics and stored at $-70{ }^{\circ} \mathrm{C}$ before being inoculated in cell cultures.

\section{Virus Isolation}

Each concentrate sample was inoculated $(0.5 \mathrm{ml} /$ flask $)$ in 2 L20B and $1 \mathrm{RD}$ cells flasks $\left(25 \mathrm{~cm}^{2}\right)$ using standard operating procedures (WHO 2003; WHO 2004a). The flasks were incubated for 7 days at $36{ }^{\circ} \mathrm{C}$. Second passages were performed by equal period.

\section{Identification of the Isolates}

Virus isolates were confirmed as enteroviruses by one-step RT-PCR assay, using specific broad reactive primers $\mathrm{EVF}=5^{\prime}$-CTC CGG CCC CTG AAT GCG GCT A- $3^{\prime}$ and $\mathrm{EVR}=5^{\prime}$-ATT GTC ACC ATA AGC AGC C-3', conserved in genomes of all known human enteroviruses, as described (dos Santos et al. 2012). This pair of primers is used routinely in the Enterovirus Laboratory for the molecular diagnosis of enteroviruses. Briefly four microliters of the cell culture suspension containing the isolated viruses were added to the PCR mix, composed of $50 \mathrm{pmol}$ of each primer, $12.5 \mu \mathrm{l}$ of GoTaq Green Master Mix (Promega, Fitchburg, WI, USA), and PCR water to a final volume of $25 \mu \mathrm{l}$. PCR was performed with a prior denaturation step of $3 \mathrm{~min}$ at $95{ }^{\circ} \mathrm{C}$ and 35 cycles of $45 \mathrm{~s}$ at $95{ }^{\circ} \mathrm{C}, 45 \mathrm{~s}$ at $55^{\circ} \mathrm{C}$, and $45 \mathrm{~s}$ at $70^{\circ} \mathrm{C}$, with a final extension of $7 \mathrm{~min}$ at $70^{\circ} \mathrm{C}$ in a thermocycler GeneAmp PCR System 9700 (Applied Biosystems, Foster City, CA, USA). The visualization of the PCR amplified products was done by electrophoresis on $10 \%$ acrylamide gels, using the 50 bp marker (Invitrogen, Carlsbad, CA, USA), staining with $0.1 \mu \mathrm{g} / \mathrm{ml}$ ethidium bromide. PVs isolates were identified as such by primers panPV PCR-1 $5^{\prime}$-T 
TIAIIGC(A/G)TGICC(A/G)TT(A/G)TT-3' ${ }^{\prime}$; panPV PCR-2 $5^{\prime}$-CITAITCI(A/C)GITT(C/T)GA(C/T)ATG-3' and at the serotype level using the sets seroPV1,2S $5^{\prime}$-TGCGIGA $(\mathrm{C} /$ T)ACIACICA(C/T)AT-3'; seroPV1A 5'-ATCATICT(C/T) TCIA(A/G)CAT(C/T)TG-3'; seroPV2A, 5'-A(C/T)ICC $(\mathrm{C} /$ T)TCIACI $(\mathrm{A} / \mathrm{G}) \mathrm{CICC}(\mathrm{C} / \mathrm{T}) \mathrm{TC}-3^{\prime}$; seroPV3S, 5'-AA(C/T) $\operatorname{CCITCI}(\mathrm{A} / \mathrm{G}) \mathrm{TITT}(\mathrm{C} / \mathrm{T}) \mathrm{TA}(\mathrm{C} / \mathrm{T}) \mathrm{AC}-3^{\prime}$; and seroPV3A, 5'-CCIAI(C/T)TGITC(A/G)TTIG(C/T)(A/G)TC-3', described elsewhere (Kilpatrick et al. 1996, 1998, 2009) as recommended by WHO (WHO 2004b).

\section{Genomic Characterization of the Poliovirus Isolates}

PVs isolates were characterized as vaccine or wild strains by multiplex RT-PCR, using a PVs Diagnostic PCR Kit (CDC, Atlanta, GA, USA) containing Sabin-specific primers (Sabin1R = 5'-TCCACTGGCITCAGTGTT-3'; Sabin1F = 5AGGTCAGATGCTTGAAAGC-3'; Sabin2R = 5' -CGGCTT GTGTCCAGGC-3; Sabin2F $=5^{\prime} \sim$ CCGTTGAAGGGATTACTAAA-3'; Sabin3R = 5'-TAAGCTATCCTGTTGCC-3'; and Sabin3F $=5^{\prime}$-AGGGCGCCCTAACIYTG-3 $3^{\prime}$ as described by Yang et al. (1991). 5'-AGGGCGCCCTAACIYTG-3'. Programmed amplification cycles: thirty cycles of denaturation: $94{ }^{\circ} \mathrm{C} / 30 \mathrm{~s}$; annealing: $62{ }^{\circ} \mathrm{C} / 45 \mathrm{~s}$; extension: $72{ }^{\circ} \mathrm{C} / 1 \mathrm{~min}$ in a GoTaq Green Master Mix (Promega, Fitchburg, WI, USA) buffer system. Reaction products were visualized in polyacrylamide gel at $10 \%$, staining with $0.1 \mu \mathrm{g} / \mathrm{ml}$ ethidium bromide, according to WHO Guidelines (WHO 2004b).

All PVs isolates were examined in the entire VP1 gene to score the presence of mutations, the $5^{\prime}$-UTR for the identification of the three-nucleotide positions associated with neurovirulence (nt 480 for Sabin 1, nt 481 for Sabin 2 and nt 472 for Sabin 3) and, 2C and 3D genes for the presence of genome recombination according to conditions described by Kilpatrick et al. (2004).

\section{Viral RNA Extraction and Sequencing Reactions}

Viral RNA was extracted from cell culture supernatant using QIAamp Viral RNA Mini Kit (Qiagen, Santa Clara, CA, USA), according to the protocol provided by the manufacturer and the cDNA was synthesized in a $20 \mu \mathrm{l}$ mixture containing $10 \mu \mathrm{l}$ of the extracted RNA, $50 \mathrm{ng}$ of randon-primers, dNTP mix at $10 \mathrm{mM}$ each and Superscript II (Life-Technologies). Incubation was at $42{ }^{\circ} \mathrm{C}$ for 30 min. The entire VP1 coding region was amplified, using primers $\mathrm{Q} 8=5^{\prime}$-AAGAGGTCTCTATTCCACAT-3' ${ }^{\prime}$, and Y7 $=5^{\prime}$-TTT GTG TCA GCG TGT AAT GAC-3' (RicoHesse et al. 1987) while the $5^{\prime}$-UTR were amplified by the primers EVR $=5^{\prime}$-ATTGTCACCATAAGCAGCC-3' ${ }^{\prime}$ (dos Santos et al. 2012) and S1-1S (5'-TTAAAACAGCTCTGGGGTTG-3'). Reactions contained $5 \mu \mathrm{l}$ of cDNA, 50 pmol of each primer, GoTaq Green Master Mix (Promega,
Fitchburg, WI, USA), and water to a final volume of $50 \mu \mathrm{l}$. Cycling conditions: thirty cycles of denaturation: $94{ }^{\circ} \mathrm{C}$ $40 \mathrm{~s}$; annealing: $55^{\circ} \mathrm{C} / 40 \mathrm{~s}$; extension: $72{ }^{\circ} \mathrm{C} / 2 \mathrm{~min}$. Amplified products for VP1 gene $(\sim 1100 \mathrm{bp})$ and $5^{\prime}$-UTR ( $\sim 700 \mathrm{bp}$ ) were analyzed in $1.0 \%$ agarose gel containing ethidium bromide $(0.5 \mathrm{mg} / \mathrm{ml})$ and visualized under a UV DNA transilluminator. Cycle-sequencing reactions using the same oligonucleotide primers described above were performed using the ABI BigDye terminator cycle-sequencing ready reaction (PE Applied Biosystems, Foster City, and the sequence products were analyzed using the Hitachi 3730XL DNA Analyzer (Applied Biosystems). In order to analyze the presence of mutations in the VP1 gene and further characterize the PVs isolates as vaccine, VDPV or wild strains, the obtained VP1 sequences were compared with the Sabin 1, 2, and 3 prototype strains, respectively (GenBank accession no AY1842219, AY184220, and AY1842221) using the Blast 2.2.27 Program (Altschul et al. 1990). The same was performed for $5^{\prime}$-UTR sequences for the identification of the three known reversions in the $5^{\prime}$-UTR of the three-PVs strains (nt 480 for Sabin type 1, nt 481 for Sabin type 2, and nt 472 for Sabin type 3).

\section{Results}

\section{Virus Isolation}

The rate of viral isolation in RD and L20B cell lines was $87 \%$ (27/31) distributed as follows: 22 samples showed characteristic enteroviruses CPE only in lineage RD; one sample only in L20B and four samples in RD and L20B, simultaneously (Table 1). All non-polio enteroviruses were isolated only on RD lineage while PVs strains were isolated in RD and L20B: RD = 3 isolates; L20B = 1 isolate and $\mathrm{RD} / \mathrm{L} 20 \mathrm{~B}=4$ isolates. The lineage L20B was only able to isolate PVs (Table 1). PV strains were present in eight out of $27(29.6 \%)$ samples with viral isolation. One sample $(3.7 \%)$ was positive for PV1, five $(18.5 \%)$ for PV2, and two (7.4\%) for PV3 (Table 2). The remaining isolates were characterized as NPEV.

\section{Genomic Characterization of the Polioviruses Isolated from the Environment}

\section{VP1 Analysis}

The number of nucleotide substitutions in VP1 varied from 0 to 5 , therefore all strains were considered as Sabin-like according to WHO instructions ( $\leq 9$ nucleotide differences for serotype $1, \leq 5$ nucleotide differences for serotype 2 , and $\leq 9$ nucleotide differences for serotype 3 ) (Table 2). 
Table 1 Viral isolation in cell lineages RD and L20B from sewage samples

\begin{tabular}{lll}
\hline Cells lineages & $\begin{array}{l}\text { No. of samples with viral isolation }{ }^{\text {a }} \\
\text { no. of samples tested }(\%)\end{array}$ & $\begin{array}{l}\text { No. of poliovirus detected/no. of samples } \\
\text { with viral isolation }(\%)\end{array}$ \\
\hline RD & $22 / 31(70.9)$ & $03 / 22(13.6)$ \\
L20B & $01 / 31(3.2)$ & $01 / 01(100)$ \\
RD + L20B & $04 / 31(12.9)$ & $04 / 04(100)$ \\
Total & $27 / 31(87)$ & $08 / 27(29.6)$ \\
\hline
\end{tabular}

Isolation of enteroviruses and polioviruses in RD and/or L20B cells. Sewage sample concentrates were inoculated in cell flasks $\left(25 \mathrm{~cm}^{2}\right)$

${ }^{a}$ Samples with characteristic enteroviruses cytopathogenic effect. Total of samples tested

Table 2 Nucleotide and amino acid substitutions observed within the VP1 gene of poliovirus isolates

\begin{tabular}{|c|c|c|c|c|c|c|}
\hline \multirow{2}{*}{$\begin{array}{l}\text { Sample } \\
\text { no. }\end{array}$} & \multirow{2}{*}{$\begin{array}{l}\text { Serotype } \\
\text { isolated }\end{array}$} & \multirow{2}{*}{$\begin{array}{l}\text { No. of mutations } \\
\text { in VP1 }\end{array}$} & \multicolumn{2}{|l|}{ Nucleotide } & \multicolumn{2}{|l|}{ Amino acid } \\
\hline & & & Type of substitutions & $\begin{array}{l}\text { Nucleotide substitutions } \\
\text { at position }{ }^{\mathrm{a}}\end{array}$ & $\begin{array}{l}\text { Position of } \\
\text { AA in VP1 }\end{array}$ & $\begin{array}{l}\text { Change } \\
\text { to AA }\end{array}$ \\
\hline 05 & PV2 Sabin like & 01 & NS & A2626G & 49 & $\mathrm{~T} \rightarrow \mathrm{A}$ \\
\hline \multirow[t]{2}{*}{06} & \multirow[t]{2}{*}{ PV2 Sabin like } & \multirow[t]{2}{*}{02} & NS & $\mathrm{T} 2548 \mathrm{C}$ & 23 & $\mathrm{~S} \rightarrow \mathrm{P}$ \\
\hline & & & NS & T2909C & 143 & $\mathrm{I} \rightarrow \mathrm{T}$ \\
\hline 11 & PV2 Sabin like & 01 & NS & T2909C & 143 & $\mathrm{I} \rightarrow \mathrm{T}$ \\
\hline 12 & PV2 Sabin like & 01 & NS & T2909A & 143 & $\mathrm{I} \rightarrow \mathrm{N}$ \\
\hline \multirow[t]{5}{*}{13} & \multirow[t]{5}{*}{ PV3 Sabin like } & \multirow[t]{5}{*}{05} & NS & $\mathrm{C} 2493 \mathrm{~T}$ & 6 & $\mathrm{~T} \rightarrow \mathrm{I}$ \\
\hline & & & $\mathrm{S}$ & $\mathrm{C} 2683 \mathrm{~T}$ & 69 & - \\
\hline & & & $\mathrm{S}$ & A2698G & 74 & - \\
\hline & & & $\mathrm{S}$ & A2821G & 115 & - \\
\hline & & & NS & $\mathrm{C} 2967 \mathrm{~T}$ & 164 & $\mathrm{~T} \rightarrow \mathrm{I}$ \\
\hline \multirow[t]{2}{*}{15} & \multirow[t]{2}{*}{ PV1 Sabin like } & \multirow[t]{2}{*}{02} & NS & A2774G & 295 & $\mathrm{~K} \rightarrow \mathrm{E}$ \\
\hline & & & NS & A3059T & 194 & $\mathrm{I} \rightarrow \mathrm{F}$ \\
\hline \multirow[t]{2}{*}{16} & \multirow[t]{2}{*}{ PV2 Sabin like } & \multirow[t]{2}{*}{02} & NS & T2909A & 143 & $\mathrm{I} \rightarrow \mathrm{N}$ \\
\hline & & & $\mathrm{S}$ & A3363G & 294 & - \\
\hline \multirow[t]{3}{*}{23} & \multirow[t]{3}{*}{ PV3 Sabin like } & \multirow[t]{3}{*}{03} & NS & C2493T & 6 & $\mathrm{~T} \rightarrow \mathrm{I}$ \\
\hline & & & $\mathrm{S}$ & $\mathrm{C} 2683 \mathrm{~T}$ & 69 & - \\
\hline & & & $\mathrm{S}$ & A2869G & 131 & - \\
\hline
\end{tabular}

${ }^{a}$ Left-hand letter refers to Sabin original nucleotide; right-hand letter refers to nucleotide present on the isolated strain

$S$ synonymous mutations, $N S$ non-synonymous mutations, $A A$ amino acid, - no change AA, $A$ alanine, $E$ glutamic acid, $F$ phenylalanine, $I$ isoleucine, $K$ lysine, $N$ asparagine, $P$ proline, $S$ serine, $T$ threonine

None of the vaccine-related PVs strains showed a number of mutations sufficient to be classified as VDPV.

All Sabin-related PVs strains showed at least one nonsynonymous mutation. The sole isolate of serotype 1 presented two non-synonymous mutations $\left(\mathrm{K}^{295}\right.$ and $\left.\mathrm{I}^{194}\right)$ not located in amino acid residues considered as markers of attenuation (Table 2).

Changes at the amino acids at residues $\mathrm{I}^{143}(\mathrm{I} \rightarrow \mathrm{T})$ and $\mathrm{I}^{143}(\mathrm{I} \rightarrow \mathrm{N})$ were the most frequently mutated codons present in four of the five isolates of serotype 2 while the remaining PV2 showed a non-synonymous mutation causing an amino acid change at residue $\mathrm{T}^{49}(\mathrm{~T} \rightarrow \mathrm{A})$ (Table 2).
The two PV3 isolates showed non-synonymous mutations at nucleotide position C2493T leading to amino acid changes at residue $\mathrm{T}^{6}(\mathrm{~T} \rightarrow \mathrm{I})$ of VP1. One of them showed the non-synonymous mutation at nucleotide C2967T with amino acid change at position $\mathrm{T}^{164}(\mathrm{~T} \rightarrow \mathrm{I})($ Table 2$)$.

\section{5'-UTR Analysis}

No substitution was identified for the Sabin type 1 isolate at the position 480. Four out of five Sabin 2 isolates showed the substitution $\mathrm{A} 481 \mathrm{G}$, associated to the neurovirulent phenotype while only one of the Sabin 3 isolates presented the substitution $\mathrm{U} 472 \mathrm{C}$, also associated with neurovirulence. 


\section{C and 3D Genes Analysis}

RT-PCR analysis of the isolates in both $2 \mathrm{C}$ protease and $3 \mathrm{C}$ polymerase showed no evidence of genome recombination with other PVs or non-polio enterovirus species.

\section{Discussion}

While eradication is not achieved, the circulation of wild strains and VDPVs will continue to challenge the global eradication of polio (Kew et al. 2005; Minor 2009; Roivanem et al. 2010).

In support of the global polio eradication activities in Brazil, this study aimed to isolate and characterize circulating PVs from wastewater collected in a large WWTP attending $\sim 1.5$ million inhabitants in Rio de Janeiro city and to establish the environmental surveillance at the Enterovirus RRL/Fiocruz.

In the present study, the rate of polio + non-polio enterovirus isolation in L20B and RD cell lines was $87 \%$, in agreement with a work by Vinjé et al. (2004), which reported $85 \%$.

The detection of non-polio enteroviruses in the samples is an indication that the environmental monitoring is being adequately performed because at least $30 \%$ of non-polio enterovirus are expected to be found in samples processed by the Grab method (Lewis and Metcalf 1988; WHO 2003). Accordingly, Sabin-related polioviruses should also be encountered in OPV-vaccinated populations especially during and after national immunization campaigns (WHO 2003).

Vulnerable groups such as immunodeficient individuals exposed or vaccinated with OPV may contribute to the circulation of $\mathrm{PVs}$ in the environment for long periods (Kew et al. 2005; Khetsuariani et al. 2010; Lodder et al. 2012). The presence of at least $1 \%$ of divergence in VP1 gene for serotypes 1 and 3 and $0.6 \%$ for serotype 2 , in comparison with the prototype strains, classifies them as VDPV. PVs with lower divergences than these are considered "Sabin-like" (Blomqvist et al. 2010). This demarcation of $\sim 1 \%$ difference in nucleotide sequence of VP1 indicates that replication of the vaccine virus has occurred for approximately one year (Kew et al. 2005).

All PVs strains isolated in this study showed few nucleotide differences compared with the prototype vaccine strains. Thus, VDPVs were not detected among the isolates. Similar results were reported by Gregio (2006) studying Sabin-related PVs from wastewater samples collected in São Paulo state, Brazil.

One serotype 2 isolate collected one week after the national immunization campaign held on June 18, 2012, showed the presence of a non-synonymous mutation in the amino acid $\mathrm{I}^{143}(\mathrm{~T} \rightarrow \mathrm{I})$. It is possible that the referred mutation arose in the early stages of the Sabin type 2 replication. It is suggested, therefore, that the $\mathrm{I}^{143}$ substitution present in this isolate has emerged in the early stages of viral replication in the vaccine recipients.

In a previous study analyzing clinical isolates, changes in the amino acid I143 $(\mathrm{I} \rightarrow \mathrm{T})$ for serotype 2 was consistently observed (Costa 2011). It can be deduced that these mutations are common in circulating poliovirus, as it is also observed in PVs isolated from clinical cases and may represent a risk to susceptible individuals since this might represent some degree of loss of attenuation.

Although in small number it was observed that serotype 1 PVs was less frequent $(12.5 \%-01 / 08)$ than serotypes 2 $(62.5 \%-05 / 08)$ and $3(25 \%-02 / 08)$, which is consistent with the data reported in New Zealand, by Huang et al. (2005) and Cordoba, Argentina (Mueller et al. 2009). It is believed that this difference may be related to the amount of excreted virus particles; the duration of excretion; the virus stability in the environment or in the ability to be transmitted from vaccine-recipient individuals to their contacts (Mueller et al. 2009).

An environmental monitoring study done by Roivainen et al. (2010) showed that strains of VDPVs were repeatedly detected in sewage in Finland. Although no suspected polio cases have been reported in the country since 1985, the authors of this study emphasized the importance of maintaining high vaccination coverage rates and environmental monitoring (Roivanen et al. 2010).

Due to the present circulation of wild and VDPV's in some countries of the globe, regions with immunization coverage rates below the desired or non-homogeneous coverage may have groups of susceptible individuals. Therefore, the environmental surveillance of polioviruses is essential during the final stages of the global polio eradication.

\section{Conclusions}

Environmental surveillance has been used successfully in monitoring the circulation of enteroviruses and has crucial importance in the final stages of the WHO global polio eradication initiative. Our results show the continuous circulation of Sabin-like PVs and absence of VDPV's in the analyzed area during the study period. We can then infer that the local vaccine coverage has been able to maintain the area free of wild and VDPV's.

Acknowledgments We would like to thank CEDAE (Rio de Janeiro State Environmental agency) for supplying the sewage samples under the agreement with Fiocruz.

Financial support $\mathrm{CNPq}, \mathrm{CGLAB/MS}$, IOC/Fiocruz. 
Open Access This article is distributed under the terms of the Creative Commons Attribution 4.0 International License (http://creati vecommons.org/licenses/by/4.0/), which permits unrestricted use, distribution, and reproduction in any medium, provided you give appropriate credit to the original author(s) and the source, provide a link to the Creative Commons license, and indicate if changes were made.

\section{References}

Altschul, S. F., Gish, W., Miller, W., Myers, E. W., \& Lipman, D. J. (1990). Basic local alignment search tool. Journal of Molecular Biology, 215(3), 403-410.

Baggi, F., Demarta, A., \& Peduzzi, R. (2001). Persistence of viral pathogens and bacteriophages during sewage treatment: lack of correlation with indicator bacteria. Research in Microbiology, $152,743-751$.

Blomqvist, S., Klemola, P., Kaiialainen, S., Paananen, A., Simonen, M. L., et al. (2010). Co-circulation of coxsackieviruses A6 and A10 in hand, foot and mouth disease outbreak in Finland. Journal of Clinical Virology, 48(1), 49-54.

Boom, R., Sol, C. J. A., Salimans, M. M. M., Jansen, C. L., et al. (1990). Rapid and simple method for purification of nucleic acid. Journal of Clinical Microbiology, 28(3), 495-503.

Cann, A. J., Stanway, G., Hughes, P. J., Minor, P. D., Evans, D. M., et al. (1984). Reversion to neurovirulence of the live-attenuated Sabin type 3 oral poliovirus vaccine. Nucleic Acids Research, 12, 7787-7792.

Carvalho, L. H. F., \& Weckx, L. Y. (2006). Uso universal da vacina inativada contra poliomielite. Jornal de Pediatria, 82(3), s75s82.

CDC. (1993). Progress toward global eradication of poliomyelitis, 1988-1991. Morbidity and mortality weekly report. Retrieved March 18, 2015, from http://www.cdc.gov/mmwr/preview/ mmwrhtml/00021026.htm.

Costa, E. V. (2011). Perfil genômico dos poliovírus de origem vacinal isolados de casos de paralisias flácidas agudas, no Brasil, no período pós-eliminação dos poliovírus selvagens da Região das Américas, PHD Thesis, Fundação Oswaldo Cruz, Rio de Janeiro, pp. 103.

Dos Santos, G. P. L., Burlandy, F. M., da Costa, E. V., \& da Silva, E. E. (2012). Direct detection of enterovirus genome in cell-culture negative cerebrospinal fluid from aseptic meningitis cases in Brazil. Virus Review \& Research, 17(1-2), 39-43.

Dowdle, W. R., De Gourvilee, E., Kew, O. M., Pallansch, M. A., \& Wood, D. J. (2003). Polio eradication: The OPV paradox. Reviews in Medical Virology, 13, 277-291.

GPEI (2015). Wild poliovirus list. Retrieved March 18, 2015, from http://www.polioeradication.org/Dataandmonitoring/Poliothis week/Wildpolioviruslist.aspx.

Gregio, C.R.V. (2006). Caracterização genômica de poliovírus derivado da vacina isolada a partir de amostras ambientais, PhD Thesis, Fundação Oswaldo Cruz, Rio de Janeiro, pp. 118.

Guest, S., Pilipenko, E., Sharma, K., Chumakov, K., \& Roos, R. P. (2004). Molecular mechanisms of attenuation of the Sabin strain of poliovirus type 3. Journal of Virology, 78, 11097-11107.

Hovi, T. (2006). Surveillance for polioviruses. Biologicals, 34, $123-126$.

Hovi, T., Shulman, L. M., van der Avoort, H., Deshpande, J., et al. (2012). Role of environmental poliovirus surveillance in global polio eradication and beyond. Epidemiology and Infection, 140(1), 1-13.

Huang, Q. S., Greening, G., Baker, M. G., Grimwood, K., Hewitt, J., et al. (2005). Persistence of oral polio vaccine virus after its removal from the immunization schedule in New Zealand. Lancet, 366, 396.

IBGE (2014). Estimativas populacionais para os municípios brasileiros 2014. Tabela de estimativas por município. Retrieved December 08, 2014, from ftp.ibge.gov.br/Estimativas_de_Popu lacao/Estimativas_2014/estimativa_dou_2014.pdf.

Kew, O. M., Sutter, R. W., de Gourville, E. M., Dowdle, W. R., \& Pallansch, M. A. (2005). Vaccine-derived polioviruses and the endgame strategy for global polio eradication. Annual Review of Microbiology, 59, 587-635.

Khetsuariani, N., Kutateladze, T., Zangaladze, E., Shutkova, T., Peñaranda, S., et al. (2010). High degree of genetic diversity of non-polio enteroviruses identified in Georgia by environmental and clinical surveillance, 2002-2005. Journal of Medical Microbiology, 59, 1340-1347.

Kilpatrick, D. R., Ching, K., Iber, J., Campagnoli, R., Freeman, C. J., et al. (2004). Multiplex PCR method for identifying recombinant vaccine-related polioviruses. Journal of Clinical Microbiology, 42, 4313-4315.

Kilpatrick, D. R., Nottay, B., Yang, C. F., Yang, S. J., Da Silva, E., et al. (1998). Serotype-specific identification of poliovirus by PCR using primers containing mixed-base or deoxyinosine residues at positions of codon degeneracy. Journal of Clinical Microbiology, 34(2), 352-357.

Kilpatrick, D. R., Nottay, B., Yang, C. F., Yang, S. J., Mulders, M. N., et al. (1996). Group-specific identification of poliovirus by PCR using primers containing mixed-base or deoxyinosine residues at positions of codon degeneracy. Journal of Clinical Microbiology, 34(12), 2990-2996.

Kilpatrick, D. R., Yang, C. F., Ching, K., Vicent, A., Iber, J., et al. (2009). Rapid group-, serotype-, and vaccine strain-specific identification of poliovirus isolates by real-time reverse transcription-PCR using degenerate primers and probes containing deoxyinosine residues. Journal of Clinical Microbiology, 47(6), 1939-1941.

Leisinger, M., \& Metzler, A. (1997). Use of sílica as a Carrier to recover and prepare waterborne enteric viruses for detecton by RT-PCR. Zentralblatt fur Hygiene und Umweltmedizin, 200, 283-296.

Lewis, G. D., \& Metcalf, T. G. (1988). Polyethylene glycol precipitation for recovery of pathogenic viruses, including hepatitis A virus and human rotavirus, from oyster, water, and sediment samples. Applied and Environmental Microbiology, 54, 1983-1988.

Lodder, W. J., Buisman, A. M., Rutjes, S. A., Heijne, J. C., Teunis, P. F., et al. (2012). Feasibility of quantitative environmental surveillance in poliovirus eradication strategies. Applied and Environmental Microbiology, 78(11), 3800-3805.

Macadam, A. J., Pollard, S. R., Ferguson, R., Skuce, D., Wood, D., et al. (1993). Genetic basis of attenuation of the Sabin type 2 vaccine strain of poliovirus in primates. Virology, 192, 18-26.

Minor, P. D. (1992). The molecular biology of poliovaccines. Journal of General Virology, 73, 3065-3077.

Minor, P. D. (2009). Vaccine-derived poliovirus (VDPV): Impact on poliomyelitis eradication. Vaccine, 27, 2649-2652.

MS (2013). Secretaria de Vigilância em Saúde, Departamento de Vigilância Epidemiológica, Coordenação Geral do Programa Nacional de Imunizações. Informe Técnico Campanha Nacional de Vacinação contra a Poliomielite. Retrieved April 10, 2014, from http://pni.datasus.gov.br/consulta_polio_13_selecao.asp.

Mueller, E. J., Bessaud, M., Huang, Q. S., Martinez, L. C., Barril, P. A., et al. (2009). Environmental poliovirus surveillance during oral poliovirus vaccine and inactivated poliovirus vaccine use in Córdoba Province Argentina. Applied and Environmental Microbiology, 75(5), 1395-1401. 
Otelea, D., Guillot, S., Furione, M., Combiescu, A. A., Balanant, J., et al. (1993). Genomic modifications in naturally occurring neurovirulent revertants of Sabin 1 polioviruses. Developments in Biologicals Standardization, 78, 33-38.

Pallansch, M. A., \& Roos, R. P. (2001). Enteroviruses: Poliovirus, coxsackievirus, echovirus and newer enterovirus. In D. M. Knipe, P. M. Howley, D. E. Griffin, R. A. Lamb, M. A. Martin, B. Roizman, \& S. E. Straus (Eds.), Fields virology (pp. 723-777). Philadelphia: Lippincot Williams \& Wilkins.

Racaniello, V. R. (2001). Picornaviridae: The viruses and their replication. In D. M. Knipe \& P. M. Howley (Eds.), Fields virology (pp. 685-723). Philadelphia: Lippincot Williams \& Wilkins.

Rico-Hesse, R., Pallansch, M. A., Nottay, B. K., \& Kew, O. M. (1987). Geographic distribution of wild poliovirus type 1 genotypes. Virology, 160(2), 311-322.

Roivanem, M., Blomqvist, S., Al-Hello, H., Paananen, A., Delpeyroux, F., et al. (2010). Highly divergent neurovirulent vaccinederived polioviruses of all three serotypes are recurrently detected in Finnish sewage. Euro Surveillance, 15(19), 19566.

Rouchaud, M. J., Lam, D. H., \& Racaniello, V. R. (1995). Determinants of attenuation and temperature sensitivity in the type 1 poliovirus Sabin vaccine. Journal of Virology, 69(8), 4972-4978.

Svitkin, Y. V., Cammack, N., Minor, P. D., \& Almond, J. W. (1990). Translation deficiency of the Sabin type 3 poliovirus genome: association with an attenuating mutation C472-U. Virology, 175, 103-109.

Tatem, J. M., Weeks-Levy, C., Georgiu, A., DiMichele, S. J., Gorgacz, E. J., et al. (1992). A mutation present in the amino terminus of Sabin 3 poliovirus. Journal of Virology, 66, 3197-3294. van Heerden, J., Ehlers, M. M., \& Grabow, W. O. (2005). Detection and risk assessment of adenoviruses in swimming pool water. Journal of Applied Microbiology, 99, 1256-1264.

Vinjé, J., Gregoricus, N., Martin, J., Gary, H. E, Jr, Caceres, V. M., et al. (2004). Isolation and characterization of circulation type 1 vaccine-derived poliovirus from sewage and stream waters in Hispaniola. The Journal of Infectious Diseases, 189(7), $1168-1175$.

Weeks-Levy, C., Tatem, J. M., DiMichele, S. J., Waterfield, W., Georgiu, A. F., \& Mento, S. J. (1991). Identification and characterization of a new base substitution in the vaccine strains of Sabin 3 poliovirus. Virology, 185, 934-937.

WHO (2003). Guidelines for environmental surveillance of poliovirus circulation. Retrieved March 15, 2015, from http://apps.who.int/ iris/bitstream/10665/67854/1/WHO_V-B_03.03_eng.pdf.

WHO. (2004a). Polio laboratory manual. Geneva: World Health Organization.

WHO (2004). Polio laboratory manual, 4th ed. Retrieved March 10, 2015, from http://www.who.int/vaccines/en/poliolab/WHO-PolioManual-9.pdf.

Wimmer, E., Hellen, C. U. T., \& Cao, X. (1993). Genetics of poliovirus. Annual Review of Genomics and Human Genetics, 27, 353-436.

Yang, C. F., De, L., Holloway, B. P., Pallansch, M. A., \& Kew, O. M. (1991). Detection and identification of vaccine-related polioviruses by the polymerase chain reaction. Virus Research, 20(2), 159-179.

Zurbriggen, S., Tobler, K., Abril, C., Diedrich, S., Ackermann, M., et al. (2008). Isolation of sabin-like polioviruses from wastewater in a country using inactivated polio vaccine. Applied and Environmental Microbiology, 74(18), 5608-5614. 